\title{
Effect of fungicides, botanicals and bioagents against purple blotch of onion caused by Alternaria porri
}

\author{
A.A. WANGGIKAR ${ }^{1}$, S.S. WAGH*2, D.P. KULDHAR ${ }^{2}$ AND D.V. PAWAR ${ }^{2}$ \\ ${ }^{1}$ Department of Plant Pathology, College of Agriculture, LATUR (M.S.) INDIA \\ ${ }^{2}$ Department of Plant Pathology, College of Agriculture, Vasantrao Naik Marathwada Krishi Vidyapeeth, PRABHANI \\ (M.S.) INDIA
}

\begin{tabular}{|c|c|}
\hline ARITCL & INFO \\
\hline Received & : 07.05.2014 \\
\hline Revised & : 19.08.2014 \\
\hline Accepted & : 01.09.2014 \\
\hline
\end{tabular}

\section{KEY WORDS :}

Onion, Alternaria porri, Purple blotch, In vitro and in vivo evaluation
*Corresponding author:

Email: sandeepwagh88@gmail.com

\begin{abstract}
A study was conducted in the of Department Plant Pathology, College of Agriculture, Latur, Vasantrao Naik Marathwada Krishi Vidyapeeth, Parbhani, Maharashtra, India, during 2011 to control Alternaria porri causing Alternaria blight of onion with fungicides, botanical and bio-agents. Among nine treatments, six fungicides (@ 100, 200, 250 and 500 ppm concentrations), one plant extract and two bioagents (@500 ppm) were evaluated in vitro in vivo and were found effective against $A$. porri and recorded significant inhibition of the test pathogen over untreated control. However, in vitro result revealed that in hexaconozole cent per cent $(100.00 \%)$ inhibition was observed, followed by difenoconazole ( $83.91 \%)$, mancozeb (63.58\%), P. florescence (58.94\%) and T. viride (54.45\%). The minimum per cent inhibition was observed in chlorothalonil (31.40\%) followed by plant extract NSKE (43.92\%), copper oxychloride (46.87\%) and carbandazim (47.11\%). In vivo results revealed that hexaconozole $(0.1 \%)$ was found most effective and recorded significantly least mean disease incidence $(6.03 \%)$ and intensity $(13.33 \%)$ with corresponding significantly increased bulb yield (438.00 q/ha) followed by mancozeb (@0.2\%) and copper oxychloride $(0.25 \%)$ which recorded significantly mean disease incidence of 6.83 and 8.53 per cent and intensity, 15.00 and 20.00 per cent, respectively and gave correspondingly bulb yield, respectively of 375.00 and 429.00 q/ha. The botanical tested, A. indica (@ 5\%) was found antifungal against $A$. porri and recorded significantly disease incidence $(7.96 \%)$ and intensity $(27.00 \%)$, and gave the bulb yield $(290.00 \mathrm{q} / \mathrm{ha}$ ). Both fungal and bacterial antagonists tested were found not so effective to reduce incidence and intensity, attempt increased the bulb yield over unsprayed control.
\end{abstract}

How to view point the article : Wanggikar, A.A., Wagh, S.S., Kuldhar, D.P. and Pawar, D.V. (2014). Effect of fungicides, botanicals and bioagents against purple blotch of onion caused by Alternaria porri. Internat. J. Plant Protec., 7(2) : 405-410. 